\title{
Maitokiintiöjärjestelmän päättymisen vaikutukset Suomen maitosektorille
}

Heikki Lehtonen1)

1) MTT Taloustutkimus, Luutnantintie 13, 00410 Helsinki

\section{Tiivistelmä}

Maitokiintiöjärjestelmän katsotaan haittaavan merkittävästi EU:n maitosektorin kilpailukykyä, kehitystä ja tehokkuutta etenkin tilanteessa jossa maitotuotteiden kysyntä kasvaa sekä EU:ssa että maailmanlaajuisesti. Viime vuosina on julkaistu laajalti tutkimuksia maitokiintiöjärjestelmän poistamisen vaikutuksista maitosektorilla EU:ssa ja jäsenmaittain. Tutkimusten mukaan maitokiintiöiden poistumisesta voi seurata merkittäviä alueellisia siirtymiä maidontuotannossa.

Tässä tutkimuksessa arvioidaan kiintiöjärjestelmän päättymisen vaikutuksia Suomessa. Vaikutukset riippuvat paljon epävarmasta maailmanmarkkinatilanteesta. Kansainvälisissä tutkimuksissa kiintiöjärjestelmän poistamisen vaikutukset maidon tuottajahintaan vaihtelevat $-10-30 \%$ välillä. Tuotetasolla voin ja maitojauheen hintojen arvioidaan alenevan enemmän kuin juustojen ja tuoretuotteiden.

Tutkimusmenetelmänä käytettiin DREMFIA -sektorimallia jossa maidontuotanto on yksi maatalouden päätuotantosuunnista. Maitojalosteita on mukana 18 erilaista. Kotimaiset tuotteet ovat epätäydellisiä substituutteja ulkomaisten kanssa. Maitokiintiöiden kauppa on mallinnettu 3 eri kiintiökauppa-alueella. Kiintiöjärjestelmän päättyminen on mallinnettu em. -10-30 \% hintaskenaarioiden avulla sekä korottamalla maitokiintiöitä DREMFIA -mallin kaikilla 18 tuotantoalueella 2\% vuodessa 2011-2020. Nämä seikat tekisivät kiintiöt käytännössä merkityksettömiksi vuoteen 2015, jonka jälkeen ne voitaisiin poistaa.

Tulosten mukaan maitokiintiöistä luopuminen on hyvistä markkinanäkymistä huolimatta haasteellinen Suomen maitosektorille. Jo tehdyt politiikkauudistukset (CAP -reformi) heikentävät maidon tarjontaa Suomessa, varsinkin Etelä-Suomen alueella. Peltoalalle maksettavien tukien lisäksi kannustinta maidon tuotantoon heikentää viljan hinnan nousu. Tämä korostaa maidon hintatason ja kansallisen tuen merkitystä Suomen maitosektorille. Jos EU-tasolla toteutuu keskimäärin 15\% hinnanalennus tuottajahintatasolla mitattuna, Suomen maidontuotanto ei vähenisi vielä enempää kuin $10 \%$. Noin 10\%:n EU-hintojen alennuksella maidontuotanto voisi vielä elpyä lähelle vuoden 2006 tuotannon tasoa, ja hyvän markkinatilanteen jatkuessa tuotanto kasvaisi selvästi yli nykyisen kiintiön vuoteen 2020. Tuotanto kasvaisi C1- ja C2-tukialueille ja tuotanto vähenisi Etelä- ja Pohjois-Suomessa jopa 20-30 \%. Jos hinnanalennus EU:n sisämarkkinoilla olisi 15-20\%, Suomen maidontuotanto jäisi pysyvästi $10-20 \%$ vuoden 2006 tuotantoa alhaisemmaksi. Samalla maidon tuottajahinta alenisi 10-15\% Suomessa. 25-30\%:n hinnanalennukset johtaisivat tuotannon vähenemiseen 25-32\%:lla 1,6-1,8 miljardiin litraan eli alle omavaraisuustason. Tulosten mukaan maidon hinnan alenemisen aiheuttamaa tuotantomotivaation laskua on vaikea korvata pinta-alatuilla kuten nurmituella, koska avainasemassa ovat suurten tilojen laajennukset.

Asiasanat: Maidontuotanto, maitokiintiöt, EU, maitotuotteet, maitotilat, rakennekehitys, hintatuki 


\section{Johdanto}

EU:n maidon tuotantoa on rajoitettu kiintiöjärjestelmällä vuodesta 1984. Käytännössä se tarkoittaa sitä, että moniin vuosiin ei ole ollut mahdollista havaita, miten maidon tuotanto reagoi maidon hinnan muutoksiin. Arviot EU:n maitokiintiöjärjestelmän poistamisen vaikutuksista vaihtelevat eri tutkimuksissa riippuen analyyseissä tehdyistä oletuksista tuottajien kiintiöylijäämästä (quota rent), kysynnän ja tarjonnan joustoista, perusvuodesta sekä toteutettavista kaupan vapauttamistoimista.

Muutamana viime vuotena on julkaistu laajalti tutkimuksia maitokiintiöjärjestelmän poistamisen vaikutuksista maitosektorilla EU:ssa ja EU-jäsenmaittain. Useimmat tutkimukset ottavat huomioon vuoden 2003 EU:n yhteisen maatalouspolitiikan reformin, vientitukien poistamisen sekä muutokset maidonjalostuksessa ja kansainvälisillä maitomarkkinoilla. Yleisesti ottaen tutkimukset osoittavat maitokiintiöjärjestelmän poistamisen kasvattavan EU:n maidontuotantoa 1-10 prosenttia. Arviot tuottajahinnan alenemisesta vaihtelevat 10 ja 35 prosentin välillä. Hinnan alennukset arvioidaan tuoreimmissa tutkimuksissa kuitenkin selvästi pienemmiksi kuin ennen vuotta 2003 tehdyissä tutkimuksissa joissa useissa kiintiöiden poiston arvioitiin alentavan maidon tuottajahintaa jopa $40 \%$. Maltillisimpiin tutkimustuloksiin vaikuttavat maitotuotteiden kysynnän kasvu sekä EU:ssa että maailmanlaajuisesti, nopeasti nousevat kustannukset maataloudessa, EU:n vuonna 2003 päätetty maatalouspolitiikan uudistus, sekä muutokset käytetyissä aineistoissa ja tutkimusmenetelmissä. EU:n yhteisen maatalouspolitiikan vuonna 2008 toteutettavan "terveystarkastuksen” (CAP health check) osalta on arvioitu, että tukien irrottaminen tuotannosta, vientitukien poistaminen ja tuontitariffien alentaminen yhdessä voisivat laskea EU:n maidon hinnan niin alas, että joillekin jäsenmaille maitokiintiöjärjestelmä tulisi merkityksettömäksi jo vuodesta 2008 lähtien.

Seuraavassa arvioidaan maitokiintiöiden poistamisen vaikutuksia maidontuotannon kokonaismäärään, maidon hintaan, maitotilojen tuloihin ja rakennekehitykseen Suomessa koko maan tasolla ja alueittain. Keskitymme arvioimaan maidontuotannon säilymis- ja kehitysedellytyksiä pitkällä aikavälillä aina vuoteen 2020. Tuotannon, investointien ja pääomakannan kehitystä raportoidaan maitotilojen eri kokoluokissa (pienet, keskikokoiset ja suuret tilat) eri hintaskenaarioilla.

\section{Aineisto ja menetelmät}

Maitokiintiöjärjestelmän poistumisella on laajoja ja monitahoisia vaikutuksia maitoalaan koko Euroopan Unionin alueella, ml. maitotilojen rakennekehitys, meijeriteollisuuden kapasiteetti ja erikoistuminen. Tässä tutkimuksessa keskitytään pääasiassa arvioimaan maitokiintiöjärjestelmän poistumisen vaikutuksia Suomessa. Tällöin on tehtävä oletuksia maitotuotteiden hinnoista EU-tasolla. Tässä turvaudutaan pääosin EU:n komission rahoittaman laajan EDIM-hankkeen luomalla tasapainomallilla tehtyihin arvioihin maitokiintiöjärjestelmän poistamisen vaikutuksista maitotuotemarkkinoille. EDIM (European Diary Industry Model) on staattinen osittaistasapainomalli, jolla mallinnetaan vertikaalisesti Euroopan unionin maitoketjua maidon tarjonnasta 14 maitojalosteen tuotantoon ja loppukysyntään. Mallissa maidon tuotanto on jaettu maitorasvan ja maitoproteiinin tuotantoon ja jalostukseen ja malli huomioi tuotannon teknologiset rajoitteet (Bouamra-Mechemache ym. 2007).

Taulukossa 1 on esitetty tässä tutkimuksessa käytetyt hintaskenaariot maitotuotteiden hinnoista EUtasolla. Lähtökohtana on ollut Kivelä \& Lehtosen (2007) kirjallisuuskatsauksessa muodostettu taulukko maitotuotteiden EU-hintojen skenaarioista. Sen mukaisesti tuoretuotteille on oletettu pienempi hintamuutos kuin voille ja maitojauheille.

Keskeinen oletus hintaskenaarioiden kannalta on oletus maitotuotteiden hinnoista ilman kiintiöiden poistumista. Tässä tutkimuksessa otettiin lähtökohdaksi, että maitotuotteiden hinnat säilyisivät ilman muita toimenpiteitä vuoden 2006 tasolla. Tätä voidaan perustella mm. sillä, että EU-markkinoilla vallitsi silloin suhteellisen stabiili tilanne jossa maitokiintiö ylitettiin ainoastaan viidessä jäsenmaassa, joista tärkeimpinä Italia ja Itävalta. Merkittävää on se, että maidontuotanto alitti selvästi kansallisen kiintiön mm. Ranskassa, Britanniassa ja mm. Unkarissa. Kiintiöiden alitukset olivat kiintiövuonna 2006/2007 selvästi ylityksiä suurempia niin, että EU:n koko kiintiöstä jäi käyttämättä 1,9 \%. Ottaen huomioon Tärkeimpinä syinä maidon tarjonnan heikkenemiseen ja kiintiöiden alittumiseen pidetään paitsi jäykkyyksiä maitokiintiöiden kaupassa eri EU-maissa, myös vuonna 2003 päätettyä CAP-reformia ja erityisesti siinä sovittua useimpien CAP-tukien, ml. maitopalkkion, irrottamista tuotantopäätöksistä (Euroopan Komissio 2007). 
Taulukko 1. Tässä selvityksessä tehdyt valinnat EU-hintaskenaarioiksi maitotuotteiden hinnoista EU:ssa.Peruskehityksessä maitokiintiöt pidetään voimassa vuoden 2007 tasolla mutta EUhintaskenaarioissa kiintiöitä kasvatetaan 2 \% vuodessa 2011-2020. Vuonna 2006 maidon tuottajahinta oli Suomessa keskimäärin 34,3 c/l. Hintaskenaariot pohjautuvat tutkimuksiin Bouamra-Mechemache et. al. 2007, Bouamra-Mechemache \& Requillart 2000 ja Colman (toim.) 2002.

\begin{tabular}{|l|c|c|c|c|c|}
\hline Skenaario & Raakamaito & Voi & Maitojauheet & Tuoretuotteet & Juusto \\
\hline $\begin{array}{l}\text { Peruskehitys } \\
\text { - maitokiintiöt } \\
\text { pidetään } \\
\text { voimassa }\end{array}$ & $\begin{array}{c}\text { Vuoden 2006 } \\
\text { taso }\end{array}$ & $\begin{array}{c}\text { Vuoden 2006 } \\
\text { taso }\end{array}$ & $\begin{array}{c}\text { Vuoden 2006 } \\
\text { taso }\end{array}$ & $\begin{array}{c}\text { Vuoden 2006 } \\
\text { taso }\end{array}$ & $\begin{array}{c}\text { Vuoden 2006 } \\
\text { taso }\end{array}$ \\
\hline $\mathbf{- 1 0} \%$ & $-10 \%$ & $-15 \%$ & $-10 \%$ & $-5 \%$ & $-5 \%$ \\
\hline $\mathbf{- 1 5} \%$ & $-15 \%$ & $-20 \%$ & $-10 \%$ & $-10 \%$ & $-10 \%$ \\
\hline $\mathbf{- 2 0} \%$ & $-20 \%$ & $-30 \%$ & $-20 \%$ & $-15 \%$ & $-15 \%$ \\
\hline $\mathbf{- 2 5} \%$ & $-25 \%$ & $-35 \%$ & $-30 \%$ & $-20 \%$ & $-20 \%$ \\
\hline $\mathbf{- 3 0} \%$ & $-30 \%$ & $-40 \%$ & $-35 \%$ & $-25 \%$ & $-25 \%$ \\
\hline
\end{tabular}

Jotta arvio vaikutuksista Suomeen olisi mahdollinen, tehtiin markkinoista ja maatalouspolitiikasta kaiken kaikkiaan seuraavat oletukset:

- Maitotuotteiden kysyntä pysyy vahvana aina vuoteen 2020 asti eli vuoden 2006 hintataso säilyy taustalla

- Vuoden 2007 hinnannousua maitotuotteissa, mikä johtuu monista samanaikaisesti tekijöistä, ei huomioida vaan se arvioidaan väliaikaiseksi

- OECD/FAO:n ennusteen mukaan maitotuotteiden maailmanmarkkinahinnoissa on vain vähäisiä muutoksia 2006-2020

- Viljojen hinnat nousevat noin $30 \%$ vuonna 2007, mutta vuonna 2013 viljan hinnat palautuvat lähemmäs vuoden 2006 tasoa eli $10 \%$ sen yläpuolelle aina vuoteen 2020 OECD/FAO:n ennusteen mukaisesti; OECD-FAO Agricultural Outlook 2007-2016

- Naudanlihan ja siipikarjanlihan hinnat säilyvät korkealla tasolla vuoteen 2020 (OECD/FAO). Naudanlihan hinta säilyy 2006 tasolla, siipikarjanlihan hinta nousee noin 10 \% vuodesta 2006

- Sianlihan hinta säilyy lähellä 2006 tasoa, muutaman prosentin sitä korkeampana vuoteen 2020

- Maatalouden ulkopuolisille tuotantopanoksille, myös energialle, inflaatio noin 1,8 \% vuodessa

- Hintaskenaarioissa (-10 \%, -15\%,-20 \%, -25 \%, -30 \%) kiintiöitä kasvatetaan 2 \% vuodessa 2011 alkaen

- Nykyiset kiintiökaupparajat säilyvät, tosin kiintiöt ja niiden kauppa menettää pian merkityksensä kun kiintiötä kasvatetaan kaikilla alueilla $2 \%$ vuodessa 
- Maidon kansallinen tuki maitolitraa kohden, samoin kuin muut tuet, pidetään alueittain vuoden 2006 tasolla

Laskelmat yo. hintaskenaarioiden ja 2011 alkavan kiintiöiden kasvattamisen (2\% / vuodessa tilakohtaisesti) tehdään MTT:n DREMFIA -sektorimallilla, joka on Suomen maatalouden päätuotantosuunnat ja niiden ulkomaankaupan kattava malli. Siinä on 18 eri tuotannollista aluetta ja tarkka tukipolitiikan kuvaus (Lehtonen 2001, 2004). Tuote- ja panoshintojen muutokset vaikuttavat eläinten ruokintaan, tuotostasoon ja pellonkäyttöön, ts. hintasuhteiden muutoksiin sopeudutaan maatalouden sisällä. Maitokiintiöiden kauppa, vuokraus ja hinnanmuodostus on mallinnettu erikseen eri kiintiökauppaalueille. Toteutuneet maitokiintiöiden hinnat ovat tärkeitä mallin validoinnissa. DREMFIA-mallia on aiemmin käytetty mm. arvioitaessa CAP-uudistusten vaikutuksia Suomen maatalouteen (Lehtonen (toim.) 2004).

DREMFIA-malli on validoitu, ts. sovitettu tuotannon ja hintojen toteutuneeseen kehitysuraan 19952020, käyttäen perusteina ensisijassa havaittua rakennekehitystä maitotiloilla ja havaittuja tuottajahintoja ja koko maan tuotantomääriä. Rakennekehitystä on mallinnettu ns. teknologisen diffuusion mallilla jossa on kolme eri tilakoko luokkaa: alle 20 lehmän tilat, 20-49 lehmän tilat sekä yli 50 lehmän tilat. Ensisijaisena validointiperusteena on käytetty lehmien jakautumista näihin tilakokoluokkiin 1995-2005. Pääoman poistoprosentti on oletettu vakioksi ja samaksi kahdelle isommalle tilakokoluokalle, mutta pienimmän tilakokoluokan poistoprosentti on ollut pakko olettaa isommaksi jotta voidaan selittää sen suhteellisen osuuden nopea lasku koko maan tasolla. Koska poistoprosentteja ei ole erilaistettu alueittain (mikä olisi epäjohdonmukaista), ja koska suurempien tilojen osuus lehmistä täytyy kasvaa virallisten rakennetilastojen mukaiseksi myös AB-alueella, malli ei selitä AB-alueen tuotannon havaittua alenemista. Tuotanto alkaa alentua mallin AB-alueella vasta 2006-2007 ja alenee aina $18 \%$, ts. selvästi alle vuoden 2006 tuotannon, vuoteen 2010. Muilta osin DREMFIA-mallin validoitu perusura noudattaa keskimäärin 1995-2006 havaittuja tuotanto- ja hintamuutoksia koko maan tasolla ja alueittain.

\section{Tulokset ja tulosten tarkastelu}

Jos EU-tasolla toteutuu keskimäärin $15 \%$ maitotuotteiden hinnanalennus (tuottajahintatasolla mitattuna), Suomen maidontuotanto ei vähenisi vielä enempää kuin $10 \%$. Noin $10 \%$ :n EU-hintojen alennuksella maidontuotanto voisi vielä elpyä lähelle vuoden 2006 tuotannon tasoa (kuva 1).

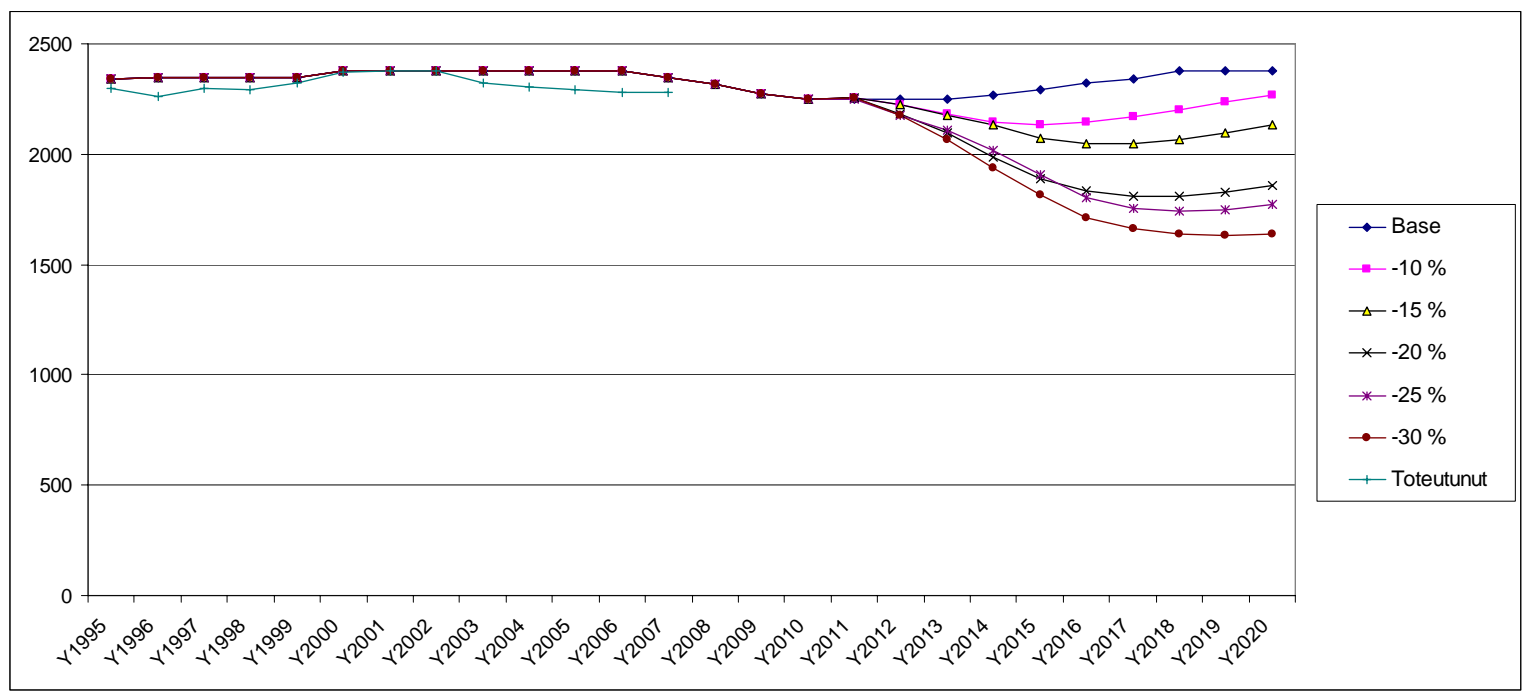

Kuva 1. Maidon kokonaistuotanto (milj. litraa) eri EU-hintaskenaarioissa

Tuotanto kuitenkin vähenisi Pohjois-Suomessa (tukialueet C2P-C4) 26 \% ja Etelä-Suomessa (ABtukialueet) $16 \%$. Tuotanto keskittyisi nykyisille vahvoille tuotantoalueilla Pohjanmaalle ja osin PohjoisSavoon. C-alueen tuotanto kasvaisi edullisten hintaskenaarioiden vallitessa, kun taas AB-alueen tuotanto palautuisi tällöin hyvin hitaasti alkuvaiheen nopean vähenemisen jälkeen (kuvat 2 ja 3).

Edellä esitetyissä tuloksissa oletettiin maidon litrakohtaisen kansallisen yksikkötuen pysyvän 20072020 vuoden 2006 tasolla. DREMFIA-mallissa C-alueiden yksikkötukea leikataan ainoastaan silloin jos 
tuotanto ylittää pohjoisen tuen säädetyn ylärajan. Litrakohtaisen tuen ei kuitenkaan oleteta kasvavan jos tuotanto vähenee. Seuraavassa arvioidaan joustavamman yksikkötuen merkitystä.

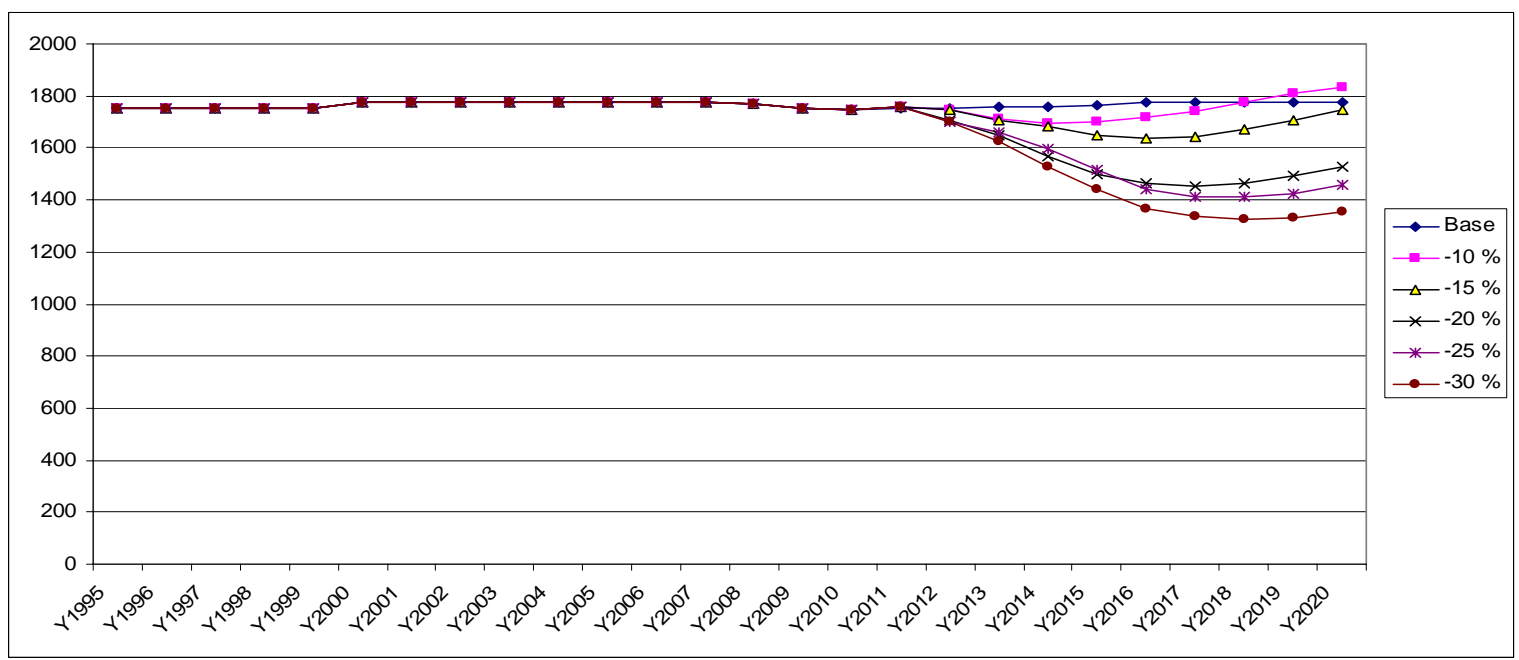

Kuva 2. Maidontuotannon kokonaismäärä (milj. litraa) yhteensä C-tukialueella

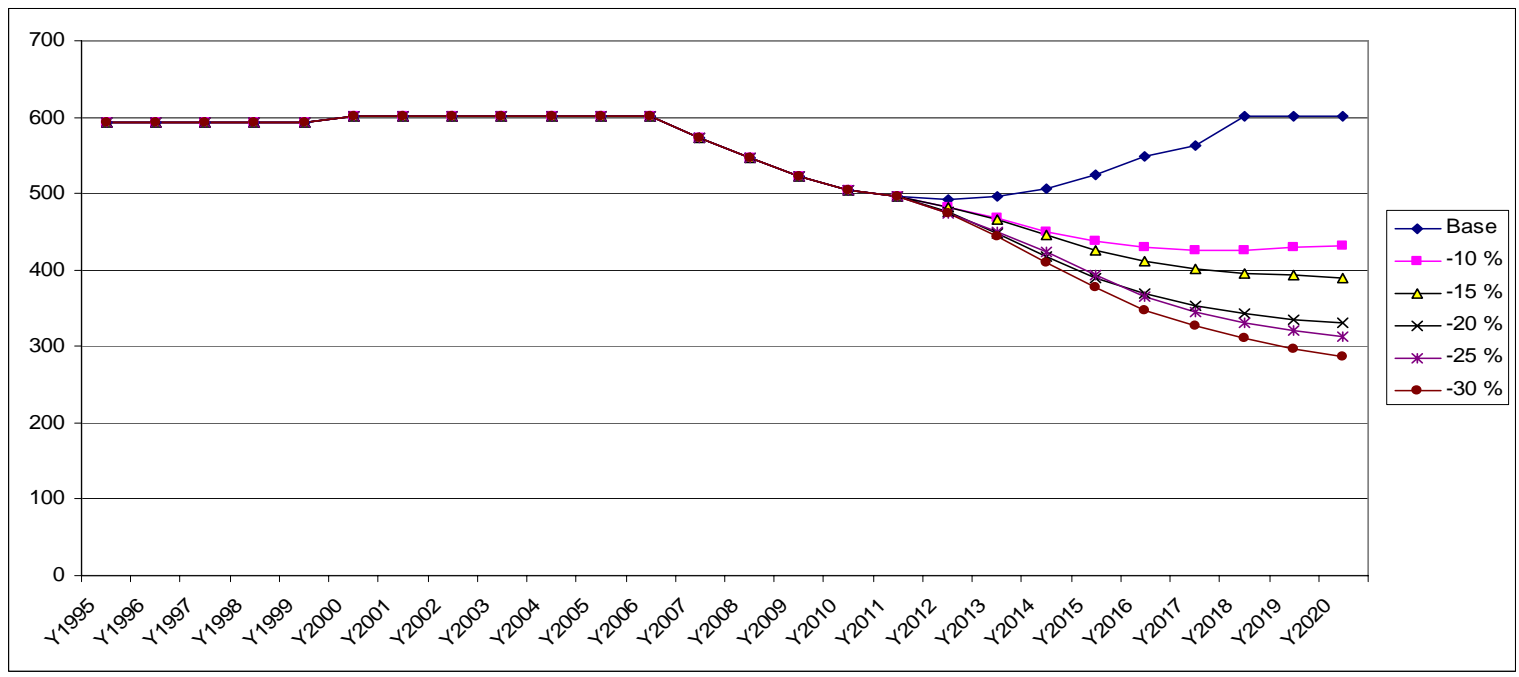

Kuva 3. Maidontuotannon kokonaismäärä (milj. litraa) AB-tukialueella

Etelä-Suomen AB-alueen maidon kansallinen hintatuki oli vuonna 2006 suuruudeltaan runsaat 15 milj. euroa. C-tukialueen vastaava summa oli noin 154 milj. euroa. Jos nämä summat voidaan jakaa erikseen AB- ja C-tukialueiden kesken kaikille maitolitroille tuotannon mukaan muuttuvana yksikkötukena, se voi vähentää selvästi arvioitujen EU-tason hintaskenaarioiden vaikutusta maidontuotantoon. Kun edellä mainitut $\mathrm{AB}$ - ja C-tukialueiden tukisummat vakioitiin em. tasolle, ja annettiin yksikkötukien riippuvan siten tuotantomääristä, saatiin eri EUhintaskenaarioista selvästi pienempi vaikutus maidontuotantoon kuin olettamalla kiinteä vuoden 2006 tukitaso. Tuen alueellinen porrastus pidettiin lähtötilanteessa eli 2011 ennallaan vuoden 2006 mukaisena, mutta jokaisen alueen tukea muutettiin suhteellisesti saman verran $\mathrm{AB}$ - tai C-alueen kokonaistuotannon muuttuessa. Tulostemme mukaan koko maan maidontuotanto jäisi tällöin kaikilla EU-tason hintaskenaarioilla noin 100 miljoonaa litraa korkeammaksi kuin jos yksikkötuet pidettäisiin vuoden 2006 tasolla (Kuva 4).

Suomen suhteellisen pieni tilakoko, keskimäärin 22 lehmää tilaa kohti vuonna 2007, sekä tilaluokkajakauman keskittyminen tämän keskikoon ympärille, tekee haasteelliseksi maitokiintiöjärjestelmän purkamisen. Monien tilojen tulisi edelleen kasvaa voimakkaasti, jotta erityisesti työnkäyttö tiloilla tehostuisi ja itse maidon tuottamisesta saatava tulo ja kate voisi vahvistua. 
Rakennekehitys ja tuotannon tehostuminen on itseään vahvistava prosessi, jossa tehokkaille tuottajille jää katetta laajennusinvestointeihin. Tämä kate ja mahdollisuudet laajennusinvestointeihin heikkenevät jos maidon hinta laskee. Kuvien 1-4 tulokset selittyvätkin pääosin kuvion 5 mukaisesta kehityksestä.

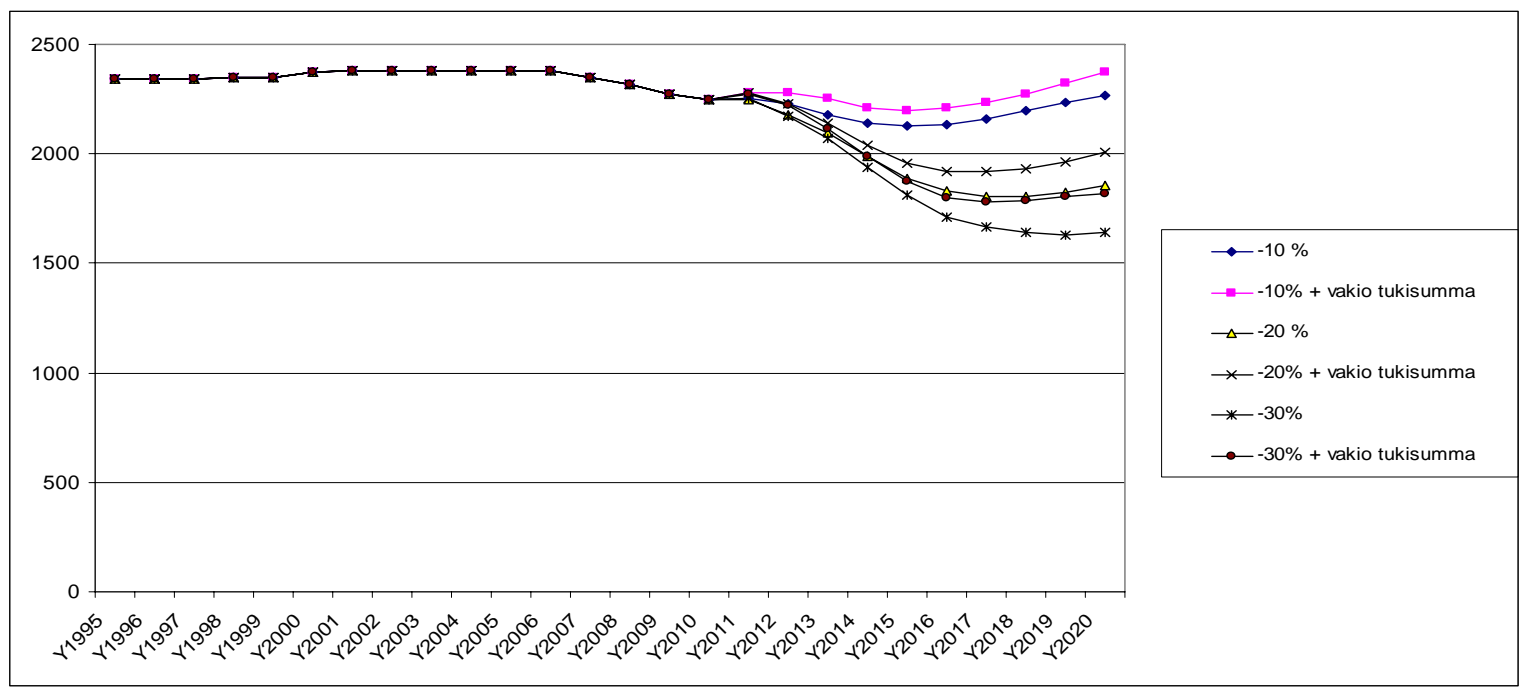

Kuva 4. Yksikkötuen suhteen joustavan kansallisen litrakohtaisen maitotuen vaikutus maidontuotantoon jos maitotuotteiden EU-hinnat alenevat $10 \%, 20 \%$ ja $30 \%$.

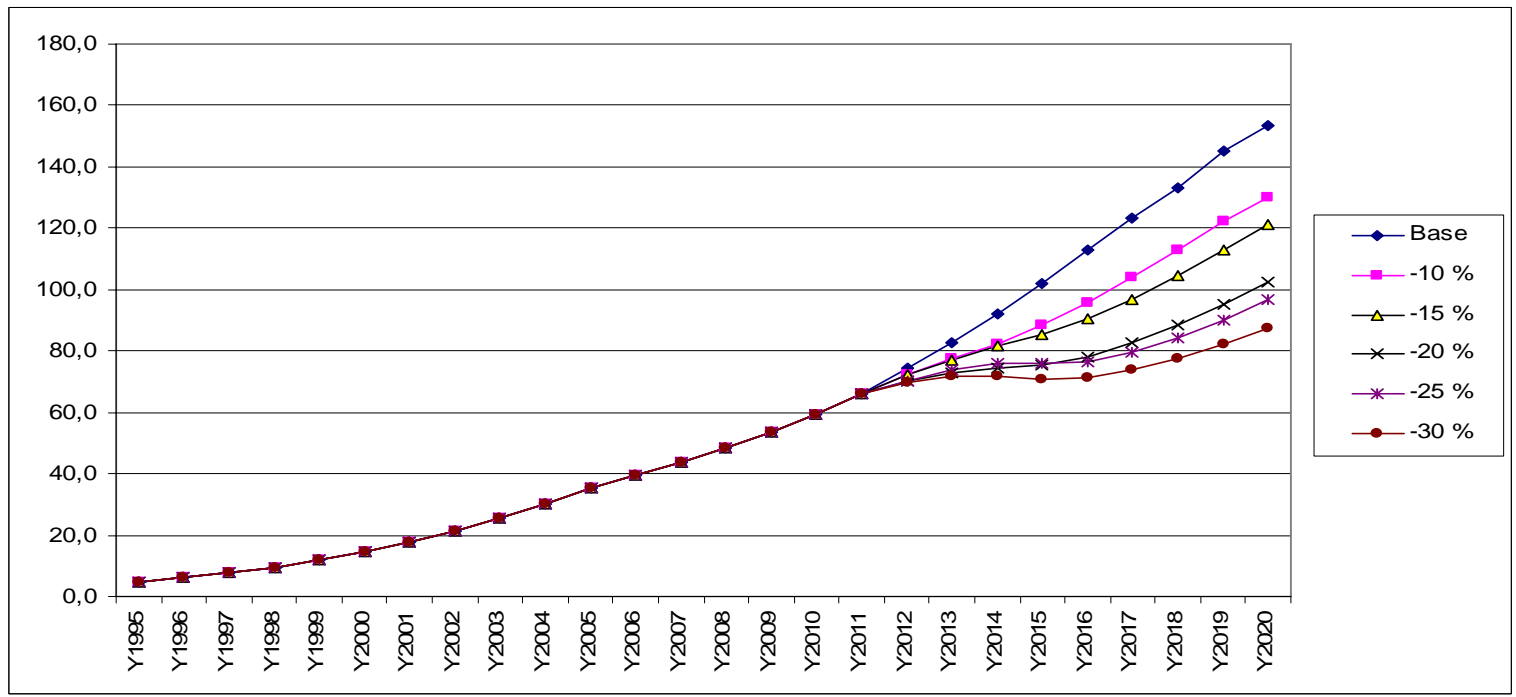

Kuva 5. Lehmäpaikkojen määrä (1000 kpl) yli 50 lehmän maitotiloilla eri hintaskenaarioissa.

\section{Johtopäätökset}

Jo tehdyt politiikkauudistukset (CAP -reformi) ja CAP-tukien irrotus tuotannosta heikentävät maidon tarjontaa Suomessa, varsinkin Etelä-Suomen alueella jossa vaihtoehtoina kasvinviljely ja muut tulot.. Tämä korostaa maidon hintatason ja kansallisen tuen merkitystä Suomen maitosektorille. Maidontuottajien tuotantomotivaatiota heikentää paitsi pinta-alatukien nousu, myös viljan hinnan nousu, OECD arvioi viljan hinnan pysyvän seuraavan 10 vuoden ajan 35 \% vuosien 2001-2005 korkeampana.

Jos maitokiintiöistä luopuminen tai niiden nopea kasvattaminen johtaa keskimäärin korkeintaan maidon 15\%:n hinnanalennukseen (tuottajahintatasolla mitattuna) maitotuotteissa EU:n sisämarkkinoilla, Suomen maidontuotanto ei vähenisi enempää kuin 10\%. Noin 10\%:n hinnanalennuksella maidontuotanto voisi vielä elpyä lähelle vuoden 2006 tuotannon tasoa 2279 milj. litraa. Tuotanto kuitenkin vähenisi 
Pohjois-Suomessa ja Etelä-Suomessa 20-30\%. Tuotanto keskittyisi C1- ja C2-tukialueille. Joitakin keskittymiä olisi eri puolilla maata, myös Etelä-Suomessa, mutta suuressa osassa Suomea maidontuotanto alenisi voimakkaasti. Rakennekehitys ja tuotannon tehostuminen itseään vahvistavana prosessina, jossa tehokkaille tuottajille jää katetta laajennusinvestointeihin, hidastuu merkittävästi jos maidon hinta alenee.

Suomen perusongelmana maitokiintiöjärjestelmän alasajossa ei kuitenkaan ole pelkästään maidon hinnanlaskun seurauksena toteutuva tuotannon kannattavuuden, maitotilojen kasvun ja tuotantomotivaation heikkeneminen. Pitkään vahvana jatkuva maitotuotteiden kysyntä ja hinnat voivat johtaa kiintiöiden kasvaessa ja aikanaan poistuessa maidon tuotannon selvään kasvuun myös Suomessa, erityisesti C-tukialueilla. Tällöin kansallisen tuen maksaminen litraperusteisesti on ristiriidassa sen kanssa, että pohjoisen tuen tarkoitus on ylläpitää maidontuotantoa Suomessa, mutta ei kasvattaa sitä. Suomessa tarvittaisiin siis kansallisen tuen järjestelmä, joka hyvässä suhdannetilanteessa antaisi mahdollisuuden tuotannon kasvuun ja tehostumiseen vahvoilla tuotantoalueilla, ja toisaalta huonoissa suhdannetilanteissa voisi toimia tuotannon jatkuvuuden turvaajana. Esimerkiksi tuen irrottaminen tuotannosta ei turvaa tuotannon jatkuvuutta kun maidon hinta on alhainen. Vastaavasti nykyinen tukijärjestelmä johtaa tulosten mukaan tuotannon selvään kasvuun C-tukialueilla, mikäli maitotuotteiden kysynnän vahva kasvu maailmalla jatkuu. Hyvin todennäköistä on kuitenkin se, että kysynnän kasvu ennen pitkää pysähtyy, ja jos sitä ennen muissa, olosuhteiltaan edullisissa EU-maissa on rakennettu runsaasti kapasiteettia maidon ja maitotuotteiden tuotantoon, hintataso voi laskea merkittävästi pitkäksikin aikaa. Kaiken kaikkiaan maitokiintiöjärjestelmän purkaminen, joka ei jätä jäljelle suojaverkkoja huonojen suhdanteiden varalta, suosii olosuhteiltaan ja kilpailukyvyltään vahvoja tuotantoalueilla Euroopassa samalla tavalla kuin edellä esitetty analyysi osoittaa tapahtuvan Suomen sisällä. On tärkeää löytää politiikkakeinot, joilla maidontuotannon jatkuvuus voidaan turvata Suomessa niin, että markkinoiden mahdollisuudet voidaan hyödyntää niin että tuotannon kasvu ei vahvoilla alueilla tule ongelmaksi. EU:n yhteinen maatalouspolitiikka lähtee siitä, että maataloutta kehitetään ensisijaisesti kysynnän ja markkinoiden ohjaamana, ei ensisijaisesti tukiin turvautuen. Tuotannonala, joka ei hyödynnä markkinoiden suomia mahdollisuuksia, vaan jättäytyy tukipolitiikan varaan, ei ole pitkään elinkelpoinen.

\section{Kirjallisuus}

Bouamra-Mechemache, Z., Jongeneel, R. \& Requillart, V. 2007. The dairy industry in an expending EU policies and strategies. EDIM/KOM: Meeting at DG Agri, April 24, 2007.

Bouamra-Mechemache, Z \& Requillart, V. 2000. Analysis of EU dairy policy reform. European Review of Agricultural Economics Vol 27 (4). s. 409-430.

Colman, D. (toim.) 2002. Phasing out milk quotas in the EU. Main report to DEFRA, Scottish Executive Environment and Rural Affairs Department, National Assembly for Wales, Agriculture Department and Department of Agriculture and Rural Development, Northern Ireland, April 2002.

Euroopan Komissio 2007. Market Outlook for the Dairy Sector. Report from the Commission to the Council. Brussels, 12.11. 2007.

Kivelä, S., Lehtonen, H. 2007. Kooste EU:n maitokiintiöjärjestelmän poistamisen vaikutuksia arvioivista tutkimuksista. In: Lehtonen, Heikki (toim.). EU:n maitokiintiöjärjestelmän poistumisen vaikutukset Suomen maitosektorille. MTT:n selvityksiä 144: 7-18. http://www.mtt.fi/mtts/pdf/mtts144.pdf

Lehtonen, H. 2001. Principles, structure and application of dynamic regional sector model of Finnish agriculture. Väitöskirja. Systeemianalyysin Laboratorio, Teknillinen Korkeakoulu. Julkaisija: Maa- ja elintarviketalouden tutkimuskeskus MTT / taloustutkimus. Julkaisuja 98. Helsinki. 265 s.

Lehtonen, H. (toim.) 2004. CAP-uudistus Suomen maataloudessa. MTT:n selvityksiä 62. Saatavissa Internetistä: http://www.mtt.fi/mtts/pdf/mtts62.pdf.

Lehtonen, H. 2004. Impacts of de-coupling agricultural support on dairy investments and milk production volume in Finland. Acta Agriculturae Scandinavica, Section C - Economy, Vol. 1. Nr. 1 / April 2004, s. 46-62. 
SUOMEN MAATALOUSTIETEELLISEN SEURAN TIEDOTE NRO 23

Lehtonen, H. (toim.) 2007. EU:n maitokiintiöjärjestelmän poistumisen vaikutukset Suomen maitosektorille. MTT:n selvityksiä 144: 89 s. http://www.mtt.fi/mtts/pdf/mtts144.pdf

OECD-FAO 2007. Agricultural Outlook 2007-2016. 88 s. http://www.oecd.org/dataoecd/6/10/38893266.pdf 